\title{
Can mixed pine forests conserve understory richness by improving the establishment of understory species typical of native oak forests?
}

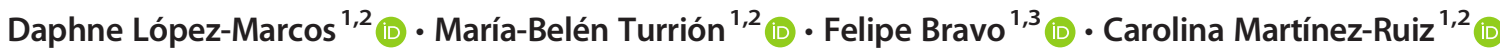

Received: 22 July 2019 / Accepted: 10 January 2020 / Published online: 4 February 2020

(C) INRA and Springer-Verlag France SAS, part of Springer Nature 2020

\begin{abstract}
- Key message A positive effect of mixed pine forests (Pinus sylvestris L. and Pinus pinaster Ait.) on the understory richness and tree regeneration was observed with respect to monospecific stands. Understory species typical of the native Pyrenean oak forests in the Iberian Peninsula contribute to maintaining high understory richness in such mixed pine forests.

- Context The influence of stands characteristics on the understory in mixtures that combine coniferous tree species of the same genus deserves more study since they are frequent in Spain.

- Aims To assess the effect of mixed versus monospecific stands of Pinus sylvestris L. and Pinus pinaster Ait. on the main tree species regeneration and understory species composition.

- Methods Tree regeneration and understory species composition were inventoried in eighteen forest plots (6 triplets) in NorthCentral Spain. Each triplet consisted of two plots dominated either by Scots pine or Maritime pine and one mixed plot that contained both species.

- Results The basal area (\%) of both Pinus species was the only characteristic of the stands that significantly influenced the understory composition and tree regeneration. Characteristic species of humid and temperate zones, including $P$. sylvestris regeneration, dominated in Scots pine stands, and typical species of well-drained Mediterranean areas, including P. pinaster regeneration, dominated in Maritime pine stands. In mixed stands, the highest regeneration of the native Pyrenean oak with respect to monospecific stands was accompanied by understory species typical of native oak forests that share the same regeneration niche. - Conclusion Mixed pine forests allow the development of understory species better than monospecific forests.
\end{abstract}

Keywords Mixed pine forests $\cdot$ Pinus sylvestris $\cdot$ Pinus pinaster $\cdot$ Pyrenean oak regeneration $\cdot$ Niche amplitude $\cdot$ Understory richness

Handling Editor: Laurent Bergès

Contribution of the co-authors Conceptualization: DLM, CMR, MBT, FB. Methodology, software: DLM, CMR. Validation: DLM, CMR. Formal analysis: DLM, CMR. Investigation: DLM, CMR, MBT, FB. Resources: CMR, MBT, FB. Data curation: DLM, FB. Writing: original draft: DLM, CMR, MBT, FB. Writing: review and editing: DLM, CMR, MBT, FB. Visualization: DLM, CMR, MBT, FB. Supervision: CMR, MBT, FB. Project administration: FB, funding acquisition: CMR, MBT, FB.

Daphne López-Marcos daphne.lopez@uva.es

María-Belén Turrión

bturrion@agro.uva.es

Felipe Bravo

fbravo@pvs.uva.es

Carolina Martínez-Ruiz

caromar@agro.uva.es
1 Sustainable Forest Management Research Institute, Universidad de Valladolid \& INIA, 34071 Palencia, Spain

Dpto. de Ciencias Agroforestales, Universidad de Valladolid, 34071 Palencia, Spain

Dpto. de Producció Vegetal y Recursos Forestales, Universidad de Valladolid, Palencia, 34071 Palencia, Spain 


\section{Introduction}

The management of mixed forests is becoming a new paradigm (Bravo-Oviedo et al. 2014) in order to improve natural tree regeneration (Carnevale and Montagnini 2002; Löf et al. 2018), soil conditions (Brandtberg et al. 2000), and the provision of many high-value ecosystem services, including carbon sequestration (Gamfeldt et al. 2013; López-Marcos et al. 2018) or biodiversity conservation (Barbier et al. 2008; Gómez-Aparicio et al. 2009; Cavard et al. 2011; Felton et al. 2010; Korboulewsky et al. 2016); additionally, under certain conditions, mixed forests can produce higher yields than monocultures (Gamfeldt et al. 2013; Jactel et al. 2018; Pretzsch et al. 2010; Saetre et al. 1997; Toïgo et al. 2015).

Since the overstory tree species differ in their effects on microclimatic and edaphic conditions, it has been suggested that the environment in mixed stands is more heterogeneous compared with monocultures (Barkman 1992; Saetre et al. 1997). Thus, mixed stands have the potential to host a more heterogeneous and species-rich flora (Hill 1992; Saetre et al. 1997). Additionally, the greater variability of habitat conditions in mixed stands than in monospecific stands may be a favorable condition for seed dispersers, and germination and growth of native tree species (Carnevale and Montagnini 2002). The structure of the stands can also influence the establishment of native species through biotic interactions such as competition (Grace and Tilman 2003) and facilitation (Brooker et al. 2008; Bruno et al. 2003; Callaway 2007). Therefore, regeneration of mixed forests has become an important topic of practical concern throughout the world (Löf et al. 2018).

The mass ratio hypothesis predicts that the ecosystem function is driven by the (traits of the) most abundant species in plant communities (Ali and Yan 2017; Grime 1998), such as specific leaf area or leaf nitrogen and phosphorus concentrations (Ali and Yan 2017). This hypothesis uses the relative abundance of each plant species to predict the effect of the most abundant species of plant communities on the ecosystem functions and services, like biodiversity (Ali and Yan 2017; Grime 1998). The application of this hypothesis is restricted to the role of autotrophs in ecosystem processes, and it postulates that the relationships between plant diversity and ecosystem properties can be explored by classifying species into categories, as dominants and subordinates (Grime 1998). Dominants are relatively large and make a substantial contribution to the plant community biomass, whereas subordinates show high fidelity of association with particular vegetation types but they are smaller and tend to occupy microhabitats delimited by the architecture and phenology of their associated dominants (Grime 1998).

Most reports of the overstory-understory relationship in mixed forests focus on mixtures that combine deciduousconiferous tree species (Barbier et al. 2008; Cavard et al.
2011; Inoue et al. 2017; Saetre et al. 1997, 1999). They test the overstory effect on the understory biomass, songbirds, soil fauna, and ectomycorrhizae (Cavard et al. 2011), cover and structural heterogeneity (Saetre et al. 1997), plant biodiversity and the associated mechanisms (Barbier et al. 2008; Rodríguez-Calcerrada et al. 2011), the spatial relationship between the overstory and understory species distribution and soil nitrogen availability (Inoue et al. 2017), soil fauna diversity (Korboulewsky et al. 2016), or soil microbial biomass and activity (Saetre et al. 1999). However, the effect of the stand characteristics on the understory in mixtures that combine coniferous tree species or even tree species of the same genus remains virtually unknown (but see Mestre et al. 2017 and López-Marcos et al. 2019). This is so despite these mixtures being frequent in many environments, such as the admixtures of Scots pine (Pinus sylvestris L.) and Maritime pine (Pinus pinaster Ait.) in Spain. Both Pinus species show similar crown architecture and slight differences in shade tolerance (Riofrío et al. 2017a) but differ in water-stress tolerance (López-Marcos et al. 2019). They are two of the main forest species in Spain and grow in pure and mixed stands either naturally or as a result of species selection for afforestation (Serrada et al. 2008).

On the other hand, the facilitating effect of Pinus species in succession processes has already been well explored among restoration strategies such as the reintroduction of endangered tree species through the use of assisted regeneration; thus, the ecological and functional role of certain pioneer species may be of vital importance for the reestablishment of native ecosystems (Aguirre et al. 2006; Arrieta and Suárez 2006; Avendaño-Yáñez et al. 2016). Nevertheless, the use of evergreen conifers as nurse plants to establish Quercus spp. could reduce the cover of the understory and its species content (Pigott 1990). Additionally, the identification of realized niches of understory plant species and knowledge of their composition and dynamics can be important information to consider in the prediction models of potential responses to climate change (Olthoff et al. 2016).

Based on the same experiment, we found that the composition of the overstory (i.e., the proportion of Pinus species) influenced the Raunkiær's life-forms composition of the understory, with the abundance of hemicryptophytes being greater in mixed stands (López-Marcos et al. 2019). The effects of mixed versus monospecific stands on the understory were also related to soil water and fertility status (see also López-Marcos et al. 2019). In particular, mixed stands occupied areas with intermediate soil moisture whereas $P$. pinaster tolerated lower soil water content than $P$. sylvestris. The organic carbon and exchangeable magnesium stocks were also higher in mixed stands (see also López-Marcos et al. 2018). In the present paper, we addressed the influence of a mixture of these two widely distributed pine species $(P$. sylvestris and 
P. pinaster) on the understory plant community composition (at the species level) and the regeneration of main tree species, including native Quercus species, compared with monospecific stands. For that, we used the same sampling design in triplets (monospecific $P$. sylvestris, monospecific $P$. pinaster, and mixed $P$. sylvestris $p$. pinaster plots), well balanced for stand composition but not necessarily for other stand characteristics. The aims of this study were (i) to test the effect of stands characteristics on species composition in the understory and tree regeneration; (ii) to model the response of distinct understory species and tree species regeneration to stands characteristics; and (iii) to estimate the niche amplitude of the main understory species, including tree regeneration, with respect to the stands characteristics. We hypothesized that (1) the proportion of Pinus species in the overstory is the most influential stands characteristic on the understory composition and tree regeneration according to previous studies; (2) the mixture of pine species favors the regeneration of native tree species like Pyrenean oak; and (3) the regeneration of native Pyrenean oak is accompanied by a group of associated understory species that contribute to maintain a high understory species richness in mixed stands as in monospecific $P$. sylvestris stands.

\section{Material and methods}

\subsection{Study sites}

The research was carried out in eighteen forest plots (6 triplets) located in the Northern Iberian Range, in North-Central Spain $\left(41^{\circ} 47^{\prime} 35^{\prime \prime} \mathrm{N}\right.$ and $41^{\circ} 53^{\prime} 41^{\prime \prime} \mathrm{N}$ latitude, and $2^{\circ} 56^{\prime}$ $12^{\prime \prime} \mathrm{W}$ and $3^{\circ} 20^{\prime} 46^{\prime \prime} \mathrm{W}$ longitude; see López-Marcos et al. $2018,2019)$. The climate is temperate with dry or temperate summer (Cfb, Csb) according to the Köppen (1936) classification for the Iberian Peninsula. The mean annual temperature is $9.0^{\circ} \mathrm{C}$ and the annual precipitation around $800 \mathrm{~mm}$. Plots are located at an elevation ranging from $1093 \mathrm{~m}$ to $1277 \mathrm{~m}$ a.s.l. Soils are acidic with mostly sandy texture and medium to low water retention capacity (see López-Marcos et al. 2018, 2019). Nearby climax vegetation (Rivas-Martínez 1987), highly degraded by anthropogenic action, is characterized by Pyrenean oak forests (Luzulo forsteri-Quercetum pyrenaicae S. and Festuco heterophyllae-Quercetum pyrenaicae S.) or juniper forests (Juniperetum hemisphaerico-thuriferae S.).

Each triplet consisted of three circular plots of $15 \mathrm{~m}$ radius, including two plots dominated either by Scots pine or maritime pine and one mixed plot that contained both species, located less than $1 \mathrm{~km}$ from each other so that the environmental conditions were homogeneous within triplets although they could differ among distinct triplets (see López-Marcos et al. 2018 for differences in soil properties). The sampling design in triplets was well balanced for stand composition (six repetitions per stand type) but not necessarily balanced for other stand characteristics (i.e., density, total basal area, dominant height, mean quadratic diameter, age) that were intended to be similar within the triplet (avoiding biases in the sampling design) but differed between triplets to be able to be contrasted (see Table 3 in Annex). The percentage of the basal area (\%G) of the dominant species in the monospecific plots was greater than $83 \%$ or $95 \%$ for $P$. sylvestris or P. pinaster respectively, whereas the basal area percentage of both species in the mixed plots ranged from 33 to $67 \%$. The age of the selected plots ranged between 44 and 151 years, the stand density between 509 and 1429 trees $\mathrm{ha}^{-1}$, the basal area between 33.3 and $70.30 \mathrm{~m}^{2} \mathrm{ha}^{-1}$, and the dominant height between 15.60 and $25.04 \mathrm{~m}$. Traditionally, forest management consists of strip clear-cutting with soil movement and planting or sowing when necessary, and moderate thinning from below (Riofrío et al. 2019). The stands have had no silvicultural intervention or damage in the last 10 years (López-Marcos et al. 2018). There were no statistical differences in the distance between the plots of the three stands types and forests of other tree species (Quercus pyrenaica Willd., Q. faginea Lam., or Juniperus spp.; see Fig. 5 in Annex). Triplets belong to the network of permanent plots of the Sustainable Forest Management Research Institute UVa-INIA (iuFOR), and they have been previously used in a series of recent studies (Riofrío et al. 2017a, b, 2019; Cattaneo 2018; López-Marcos et al. 2018, 2019).

\subsection{Sampling of understory vegetation and tree regeneration}

Within each plot, 10 quadrats $(1 \mathrm{~m} \times 1 \mathrm{~m})$ were randomly selected and the vertical projection cover (\%) of every understory vascular plant species, including tree regeneration, and bryophytes was estimated visually by the same observer in June 2016 (López-Marcos et al. 2019) to encompass and identify the maximum number of vascular plant species (Alday et al. 2010). Vascular plant species nomenclature follows Tutin et al. (1964-1980) and bryophytes nomenclature follows Crosby et al. (1992). The number of individuals (stems) of the tree regeneration was also counted within each quadrat. Tree regeneration included the main tree species found at seedlings/saplings stages (i.e., P. sylvestris, $P$. pinaster, Q. pyrenaica, and Q. faginea) because no old regeneration was found (it had probably been cleared by management for fire prevention); only seven old individuals of Juniperus oxycedrus L. were found that were considered to be part of the understory (height $<1 \mathrm{~m}$ ) but not as regeneration, thus estimating their cover but not counting them as individuals. In these stands, there were no subordinate tree species. Only two layers of vegetation could be distinguished (overstory and understory): the overstory measuring c.a. $20 \mathrm{~m}$ and the understory never higher than $1 \mathrm{~m}$. 


\subsection{Data analyses}

The cover (\%) of each species and density of main tree species regeneration (i.e., $P$. sylvestris, $P$. pinaster, $Q$. pyrenaica, and $Q$. faginea) in each plot were calculated as the average of the 10 quadrats. Richness was calculated as the total cumulative number of plant species in the 10 quadrats per plot (Colwell 2009), including understory vegetation and tree regeneration. Although several indices of diversity were tested, only the number of species showed any difference among stand types and thus is shown in results.

To identify the characteristics of the stands that determine the understory plant species composition, a detrended correspondence analysis (DCA) was applied on the matrix of the cover of the understory plant species (30 species $\times 17$ plots). To assist in the interpretation of the ordination axes, the stand characteristics and tree regeneration were fitted as vectors onto the DCA ordination plot using the vegan "envfit" function (Oksanen 2016). The advantage of this method is that it allows for testing the significance of each vector adjusted by 9999 permutations, with the $R^{2}$ of each variable able to be calculated. The explanatory variables considered in the analysis were (1) the stands characteristics: normal age (age: years), density $\left(N\right.$ : trees ha $\left.{ }^{-1}\right)$, total basal area $\left(G: \mathrm{m}^{2} \mathrm{ha}^{-1}\right)$, dominant height (Ho: $\mathrm{m})$, quadratic mean diameter (dq: $\mathrm{cm}$ ), and the percentage of basal area $(\% \mathrm{G})$ of P. sylvestris and $P$. pinaster; and (2) the tree regeneration (individuals $\mathrm{m}^{-2}$ ) of $P$. sylvestris, $P$. pinaster, $Q$. pyrenaica, and $Q$. faginea. Additionally, in order to relate overstory composition to tree regeneration and tree regeneration to main understory species, Pearson's correlation coefficients $(p<0.05)$ between the regeneration density of the main tree species (P. sylvestris, $P$. pinaster, and $Q$. pyrenaica) and the percentages of basal area of $P$. sylvestris and $P$. pinaster, as well as between the regeneration cover (\%) of main tree species and the cover (\%) of main species of the understory, were calculated.

The response of understory plant species (total species richness and individual species cover) and tree regeneration (density: individuals $\mathrm{m}^{-2}$ ) with respect to the significant stand characteristics (i.e., the overstory composition by means of the percentage of basal area of $P$. pinaster) were modeled by Huisman-Olff-Fresco (HOF) models (Huisman et al. 1993). These are a hierarchical set of five response models, ranked by their increasing complexity (model I, monotone trend, i.e., with constant abundance; model II, increasing or decreasing trend where the maximum is equal to the upper bound; model III, increasing or decreasing trend where the maximum is below the upper bound; model IV, symmetrical response curve; Model V, skewed response curve). The Akaike information criterion (AIC; Akaike 1973) was used to select the most appropriate response model (Johnson and Omland 2004); smaller values of AIC indicate better models. HOF models were validated using "bootstrapping" because the frequency of appearance of $33 \%$ of species in the plots was low $(<10 \%$; mostly for species following HOF model I). Finally, the location of species optima $(\mu)$ and niche widths (2t) for those species with unimodal responses were derived from the HOF models (Lawesson and Oksanen 2002). The $2 \mathrm{t}$ values were found by solving for the gradient points of the fitted HOF model relative to a strict Gaussian model at $2 \mathrm{t}$ (Lawesson and Oksanen 2002). In the case of a symmetric unimodal response, the lower and upper $t$ values are identical, while with a skewed model, the $2 t$ intervals are not necessarily equal.

All statistical analyses were implemented in the R software environment (version 3.3.3; R Development Core Team 2016) using the vegan package for multivariate analyses (version 2.3-5; Oksanen 2016), and the eHOF package for HOF models (version 3.2.2; Jansen and Oksanen 2013). One monospecific plot of $P$. sylvestris was considered an outlier and excluded from all analyses because it was the only one that presented aquic conditions (see López-Marcos et al. 2019). Soils that have an aquic moisture regime are saturated long enough to cause anaerobic conditions (Soil-Survey-Staff 2014).

\section{Results}

\subsection{Effects of stand characteristics on the understory vegetation}

The DCA ordination produced eigenvalues $(\lambda)$ of 0.50 and 0.35 for the first two axes, with gradient lengths of 2.62 and $2.52 \mathrm{SD}$ units, respectively (Fig. 1). The adjustment of explanatory variables on the biplot ordination showed how the percentages of the basal area $(\% \mathrm{G})$ of $P$. sylvestris and $P$. pinaster were the stands characteristics that explained most variability $(0.7$ in both cases), with both showing an opposite tendency (Fig. 1). This suggests a gradual change in the composition of the understory related to the overstory composition. The other characteristics of the stands were not significantly correlated with the DCA ordination, and thus they are not displayed in results (but see Table 1). Thirty understory species from twenty-one families were recorded, with Ericaceae being the most frequent (88\%) and abundant (24\%) taxonomical group, with greater cover in monospecific stands of $P$. pinaster (29\%) and mixed stands (26\%), followed by bryophytes (Hypnaceae; $94 \%$ frequency and 5\% cover), most abundant in monospecific stands of $P$. sylvestris $(15 \%)$. Rosaceae was more abundant in monospecific stands of P. sylvestris (2.4\%) and mixed stands (1.8\%), and Poaceae in mixed stands $(6.3 \%)$. A wide group of families displayed residual cover $(<1 \%$; Aquifoliaceae, Asteraceae, Caryophyllaceae, Fabaceae, Geraniaceae, Juncaceae, 


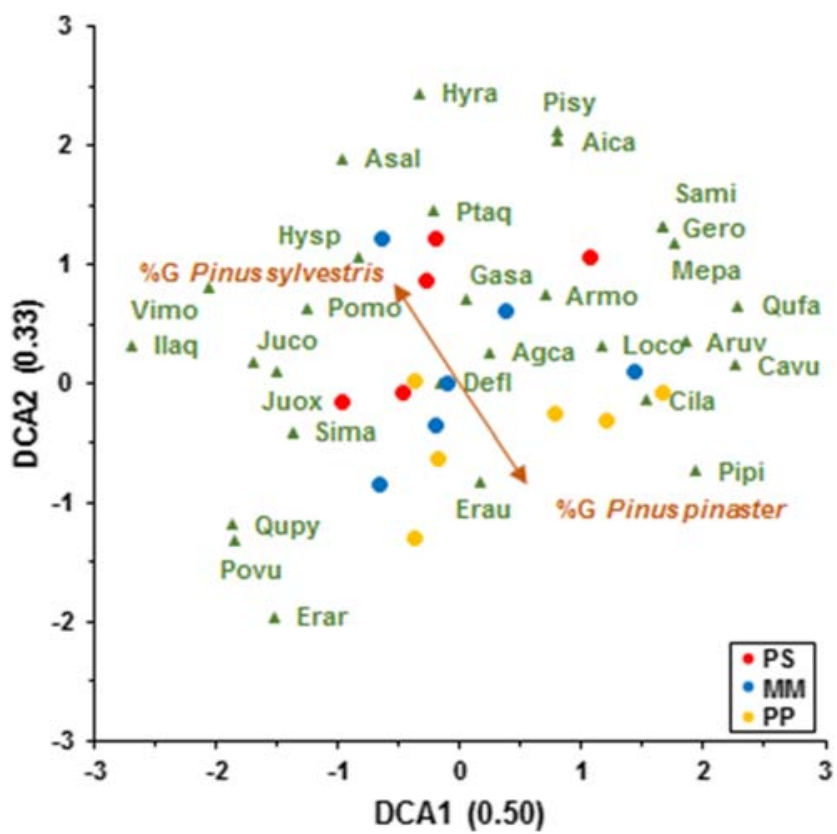

Fig. 1 DCA biplot of plots and species and projection of the significant two significant explanatory variables $(p<0.05$ and explained variation $>$ $50 \%$ ). Stands characteristics other than $\% \mathrm{G}$ of Pinus sylvestris and $\% \mathrm{G}$ of Pinus pinaster were not significantly correlated with the DCA axes. PS Pinus sylvestris monospecific plots, PP Pinus pinaster monospecific plots, and MM mixed plots of the two Pinus species. Species codes: Agca (Agrostis castellana Boiss. \& Reut), Aica (Aira caryophyllea L.), Armo (Arenaria montana L.), Aruv (Arctostaphylos uva-ursi (L.) Spreng), Asal (Asphodelus albus Mill.), Cavu (Calluna vulgaris (L.) Hull), Cila (Cistus laurifolius L.), Defl (Deschampsia flexuosa (L.) Trin.), Erar (Erica arborea L.), Erau (Erica australis L.), Gasa (Galium saxatile L.), Gero (Geranium robertianum L.), Hysp (Hypnum spp.), Hyra (Hypochaeris radicata L.), Ilaq (Ilex aquifolium L.), Juco (Juncus conglomeratus L.), Juox (Juniperus oxycedrus L.), Loco (Lotus corniculatus L.), Mepa (Melampyrum pratense L.), Pipi (Pinus pinaster Aiton), Pisy (Pinus sylvestris L.), Povu (Polygala vulgaris L.), Pomo (Potentilla montana Brot.), Ptaq (Pteridium aquilinum (L.) Kuhn), Qufa (Quercus faginea Lam.), Qupy (Quercus pyrenaica Willd.), Sami (Sanguisorba minor Scop.), Sima (Simethis mattiazzii (Vand.) Sacc.) and Vimo (Viola montcaunica Pau)

Liliaceae, Poligalaceae, Rubiaceae, Scrophulariaceae, Violaceae, and Xanthorrhoeaceae).

\subsection{Tree regeneration patterns with respect to the overstory composition}

The adjustment of tree regeneration, i.e., density (individuals $\mathrm{m}^{-2}$ ) of P. sylvestris, P. pinaster, Q. pyrenaica, and Q. faginea on the DCA ordination (Fig. 2a), showed how tree regeneration was significantly correlated with the understory composition $(r=0.61, p=0.015 ; r=0.76, p=0.001 ; r=0.64, p=$ 0.011 ; and $r=0.78, p=0.004$, respectively), and is also related to the tree overstory composition. Indeed, $P$. sylvestris regeneration was positively correlated with the percentage of basal area of $P$. sylvestris $(r=0.48, p<0.05)$ and negatively correlated with the percentage of basal area of $P$. pinaster $(r=$
Table 1 Explanatory variables fitted as vectors onto the DCA ordination plot using the vegan "envfit" function. Significance of each vector adjusted by 9999 permutations and $R^{2}$ of each variable. $N$ : density (trees ha $\left.{ }^{-1}\right), G$ : total basal area $\left(\mathrm{m}^{2} \mathrm{ha}^{-1}\right)$, Ho: dominant height $(\mathrm{m})$, dq: quadratic mean diameter $(\mathrm{cm})$, age: normal age (years); \%G PS: the percentage of basal area of Pinus sylvestris, \%G PP: the percentage of basal area of $P$. pinaster; and the tree regeneration density (individuals $\mathrm{m}^{-2}$ ) of $P$. sylvestris, P. pinaster, Q. pyrenaica, and Q. faginea

\begin{tabular}{|c|c|c|c|c|c|}
\hline & DCA1 & DCA2 & $R^{2}$ & $p$ & \\
\hline \multicolumn{6}{|c|}{ Stand characteristics } \\
\hline$\% \mathrm{G}$ PS & -0.544 & 0.839 & 0.484 & 0.019 & $*$ \\
\hline$\% \mathrm{G} P \mathrm{P}$ & 0.544 & -0.839 & 0.484 & 0.019 & $*$ \\
\hline$N\left(\right.$ trees $\left.\mathrm{ha}^{-1}\right)$ & -0.114 & -0.993 & 0.309 & 0.087 & \\
\hline$G\left(\mathrm{~m}^{2} \mathrm{ha}^{-1}\right)$ & -0.751 & -0.665 & 0.237 & 0.160 & \\
\hline Ho (m) & -0.829 & 0.559 & 0.305 & 0.081 & \\
\hline $\mathrm{dq}(\mathrm{cm})$ & -0.524 & 0.851 & 0.162 & 0.298 & \\
\hline Age (years) & -0.744 & 0.668 & 0.360 & 0.090 & \\
\hline \multicolumn{6}{|c|}{ Tree regeneration density (ind $/ \mathrm{m}^{2}$ ) } \\
\hline P. sylvestris & 0.284 & 0.959 & 0.365 & 0.015 & $*$ \\
\hline P. pinaster & 0.977 & -0.212 & 0.583 & 0.001 & $* * *$ \\
\hline Q. pyrenaica & -0.556 & -0.831 & 0.413 & 0.011 & $*$ \\
\hline Q. faginea & 0.985 & 0.171 & 0.602 & 0.004 & $* *$ \\
\hline
\end{tabular}

$-0.48, p=0.03)$. The $P$. pinaster regeneration was positively correlated with the percentage of basal area of $P$. pinaster $(r=$ $0.46, p<0.05)$ and negatively correlated with the percentage of basal area of $P$. sylvestris $(r=-0.46, p<0.05)$.

On the other hand, the regeneration of distinct tree species with respect to overstory composition (Fig. 2b) showed four different types of responses. Q. faginea (HOF model I) showed monotone response and is not shown in Fig. 2b; its presence was sporadic; only 12 individuals were found covering less than $1 \%$. P. sylvestris showed a decreasing trend (HOF model II) as the percentage of basal area of P. pinaster increased. $P$. pinaster showed an increasing trend (HOF model II) as the percentage of basal area of $P$. pinaster increased. Lastly, the regeneration of $Q$. pyrenaica exhibited a symmetrical unimodal response curve (HOF model IV), with higher density for intermediate percentages of $P$. pinaster basal area, i.e., in mixed stands. As a whole, 291 individuals of $P$. sylvestris, 215 individuals of $P$. pinaster, and 129 individuals of $Q$. pyrenaica were recorded.

\subsection{Relating the regeneration of main tree species to the species of the understory}

The regeneration cover of $P$. sylvestris was positively correlated with the cover of some hemicryptophytes (Hypochaeris radicata, Sanguisorba minor) and some therophytes (Geranium robertianum, Melampyrum pratense) and negatively correlated with the cover of the chamaephyte Erica australis (see Table 2). The regeneration cover of $P$. pinaster 
Fig. 2 a DCA of plots and projection of the significant explanatory variables $(p<0.05$ and explained variation $>50 \%$ ): "in brow" the \% $\mathrm{G}$ of Pinus sylvestris and \% G of Pinus pinaster, and "in green" the tree regeneration, i.e., individuals $\mathrm{m}^{-2}$ of Pinus sylvestris, Pinus pinaster, Quercus pyrenaica, and Quercus faginea. b HOF-derived response curves of the regeneration of tree species relative to the $\%$ of $\mathrm{G}$ of Pinus pinaster. Abbreviations as in Fig. 1 (a)

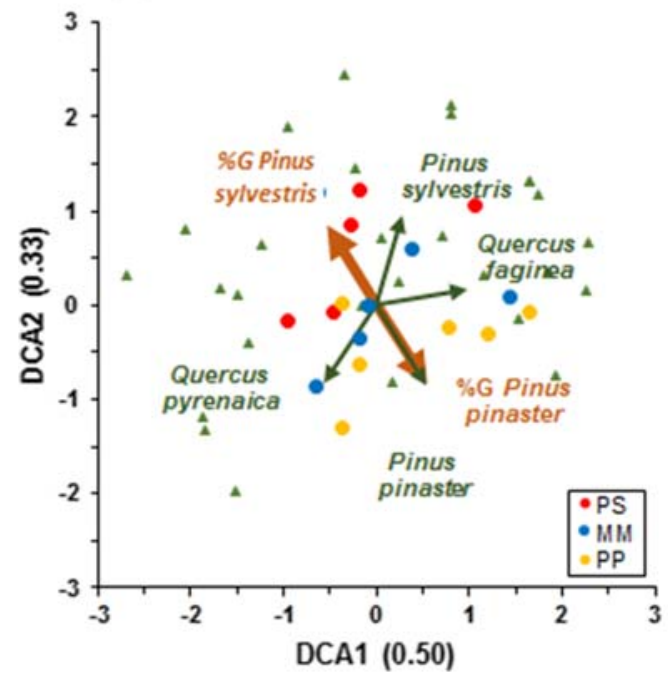

(b)

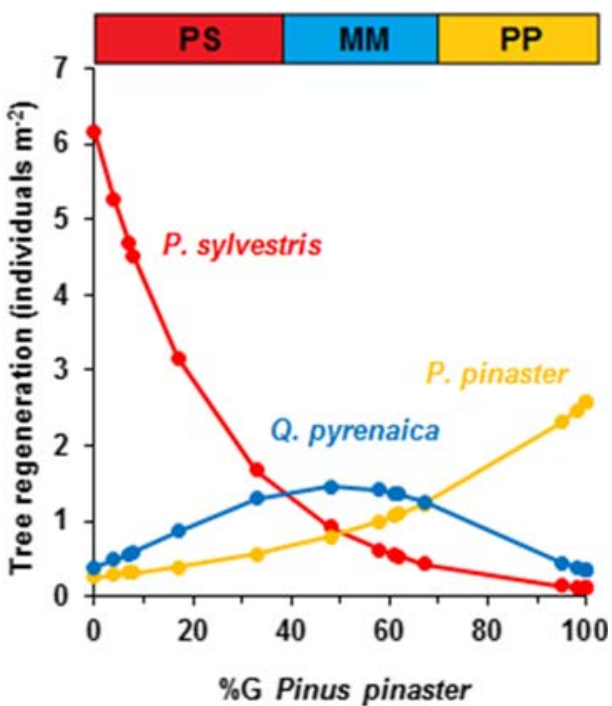

was positively correlated with the cover of Calluna vulgaris (chamaephyte) and negatively correlated with the cover of bryophytes (Hypnum spp.). The regeneration cover of Q. pyrenaica was positively correlated with the cover of some hemicryptophytes (Viola montcaunica, Polygala vulgaris, Agrostis castellana) and some shrub species: Erica arborea (chamaephyte) and Ilex aquifolium (phanerophyte).

\subsection{Understory species patterns with respect to the overstory composition}

The understory richness showed a decreasing trend bounded below the maximum attainable response where the percentage

Table 2 Pearson's correlation coefficients between the regeneration cover (\%) of main tree species, i.e., Pinus sylvestris (Pisy), Pinus pinaster (Pipi), and Quercus pyrenaica (Qupy), and the cover (\%) of main understory species. Only significant correlations are shown $(p<0.05)$. Species codes in Fig. 1

\begin{tabular}{llll}
\hline & Pisy & Qupy & Pipi \\
\hline Agca & & +0.54 & +0.80 \\
Cavu & & +0.84 & \\
Erar & & & \\
Erau & -0.46 & & -0.48 \\
Gero & +0.69 & & \\
Hyra & +0.46 & +0.57 & \\
Hysp & & & \\
Ilaq & & +0.55 & \\
Mepa & +0.68 & & \\
Povu & & +0.42 & \\
Sami & +0.69 & & \\
Vimo & & & \\
\hline
\end{tabular}

of basal area of $P$. pinaster was lower (HOF model III; Fig. 3a). Responses of individual species with respect to the overstory composition separated the understory species into four groups. Group 1 (HOF model I) included 14 species that showed a monotone response and which are not shown in Fig. 3; they mostly had cover $\leq 1 \%$ : Arenaria montana (0.09\%), Asphodelus albus (0.24\%), Galium saxatile $(0.32 \%)$, Geranium robertianum $(0.01 \%)$, Hypochaeris radicata (0.10\%), Ilex aquifolium (0.06), Juncus conglomeratus (0.09\%), Lotus corniculatus $(0.03 \%)$, Melampyrum pratense $(0.28 \%)$, Polygala vulgaris $(0.18 \%)$, Quercus faginea $(0.16 \%)$, Sanguisorba minor $(0.01 \%)$, Simethis mattiazzii $(0.12 \%)$, and Viola montcaunica $(0.28 \%)$. Group 2 (Fig. 3a) contained two species: P. sylvestris (Pisy; HOF model II) with a decreasing trend as the $P$. pinaster basal area increased; and Hypnum spp. (Hysp; HOF model V) with asymmetrical response curve and with the maximum skewed at the minimum P. pinaster basal area. Group 3 (Fig. 3b) included four woody species showing HOF model II with an increasing trend as the Pinus pinaster basal area increased, which were Arctostaphylos uva-ursi (Aruv), Pinus pinaster (Pipi), Calluna vulgaris (Cavu), and Cistus laurifolius (Cila), and two species with skewed response curve (HOF model V) with the maximum at the maximum values of Pinus pinaster basal area, which were Erica australis (Erau) and Deschampsia flexuosa (Defl). Lastly, seven species in group 4 (Fig. 3c) exhibited symmetrical unimodal response curves (HOF Model IV): Pteridium aquilinum (Ptaq), Erica arborea (Erar), Q. pyrenaica (Qupy), Juniperus oxycedrus (Juox), Aira caryophyllea (Aica), Agrostis castellana (Agca), and Potentilla montana (Pomo), with optima at different values of $P$. pinaster basal area, suggesting a gradual turnover of these species in response to the overstory composition. 


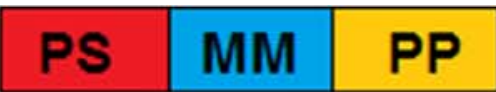

(a)

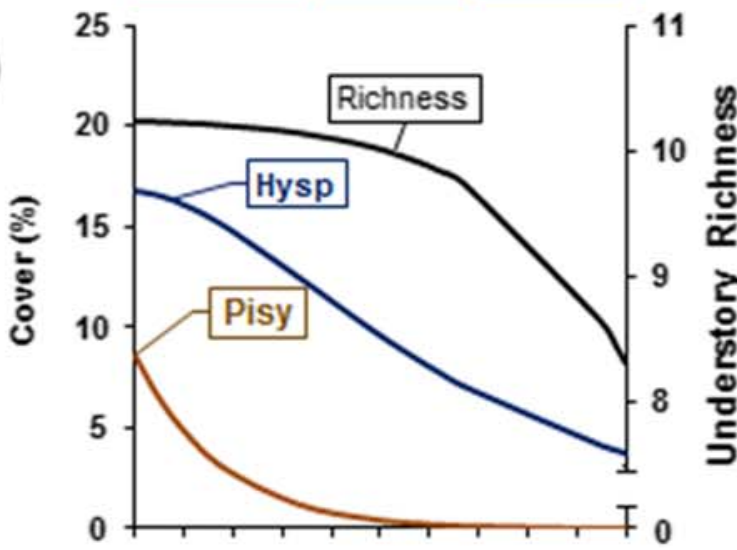

(b)

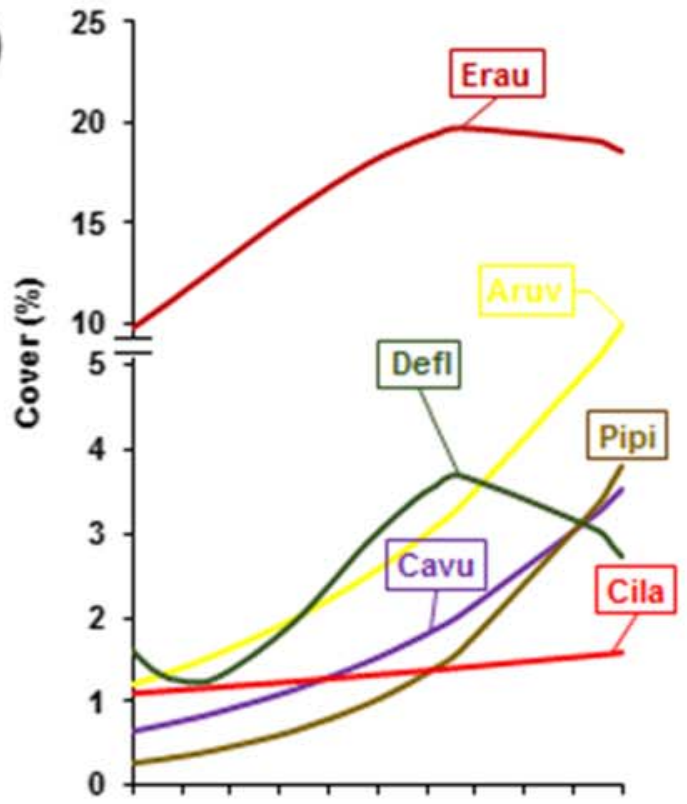

(c)

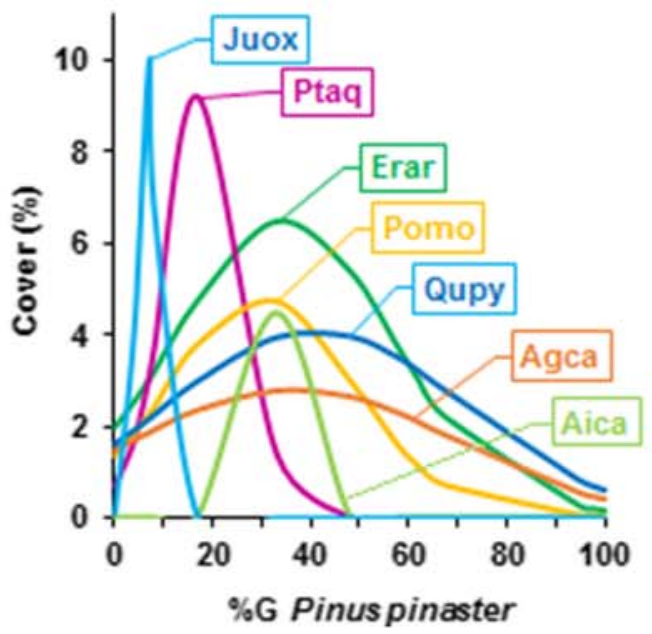

Fig. 3 HOF-derived response curves of understory species (including tree regeneration) and understory richness relative to the percentage (\%) of basal area $(\mathrm{G})$ of Pinus pinaster; the best HOF model according to the AIC criterion is showed. Graphs separated for clarity accordingly to different species-response groups. Pinus sylvestris monospecific plots (PS); Pinus pinaster monospecific plots (PP); Mixed plots of both Pinus species (MM). Species codes: Agca (Agrostis castellana Boiss. \& Reut), Aica (Aira caryophyllea L.), Aruv (Arctostaphylos uva-ursi (L.) Spreng), Cavu (Calluna vulgaris (L.) Hull), Cila (Cistus laurifolius L.), Defl (Deschampsia flexuosa (L.) Trin.), Erar (Erica arborea L.), Erau (Erica australis L.), Hysp (Hypnum spp.),Juox (Juniperus oxycedrus L.), Pipi (Pinus pinaster Ait.), Pisy (Pinus sylvestris L.), Pomo (Potentilla montana Brot.), Ptaq (Pteridium aquilinum (L.) Kuhn), Qupy (Quercus pyrenaica Willd).

\subsection{Species optima and niche widths with respect to overstory composition}

The location of the optimum of the understory species with unimodal response with respect to the overstory composition (percentage of $P$. pinaster basal area; Fig. 4, and Table 4 in Annex) showed how the two species with the greatest probability of occurrence $(h>15)$ had their optima in monospecific stands: the bryophyte Hypnum spp. with optimum in monospecific stands of $P$. sylvestris ( $\mu<33 \%$ of $P$. pinaster basal area), and the chamaephyte Erica australis with optimum in monospecific stands of P. pinaster ( $\mu>67 \%$ of $P$. pinaster basal area). Both species had large niche widths (2t of 42.55 and 43.50, respectively) and also appear in mixed stands. Juniperus oxycedrus and Pteridium aquilinum with intermediate probability of occurrence $(7<h<15)$ had narrow niche widths $(2 \mathrm{t}$ of 3.21 and 13.95 , respectively) and optima ( $\mu<33 \%$ of $P$. pinaster basal area) in monospecific stands of $P$. sylvestris. Lastly, six species (Erica arborea, Quercus pyrenaica, Aira caryophyllea, Agrostis castellana, Potentilla montana, and Deschampsia flexuosa) with low probability of occurrence $(h<7)$ have their optimum mostly in mixed stands ( $\mu=30-70 \%$ of $P$. pinaster basal area) and showed, in general, large niche widths and appear in two or three types of stands.

\section{Discussion}

\subsection{Stand characteristics that influence the understory}

Our results showed how the percentage of basal area $(\% \mathrm{G})$ of the two Pinus species (P. sylvestris and P. pinaster) is the only characteristic of the stand, among the variables tested in this study, which significantly influenced the understory composition and tree regeneration, in agreement with hypothesis 1 . The other stands characteristics tested (i.e., density, total basal area, dominant height, mean quadratic diameter, age) had no detectable influence on the understory because the tree species composition was the main varying factor (see López-Marcos et al. 2018). 


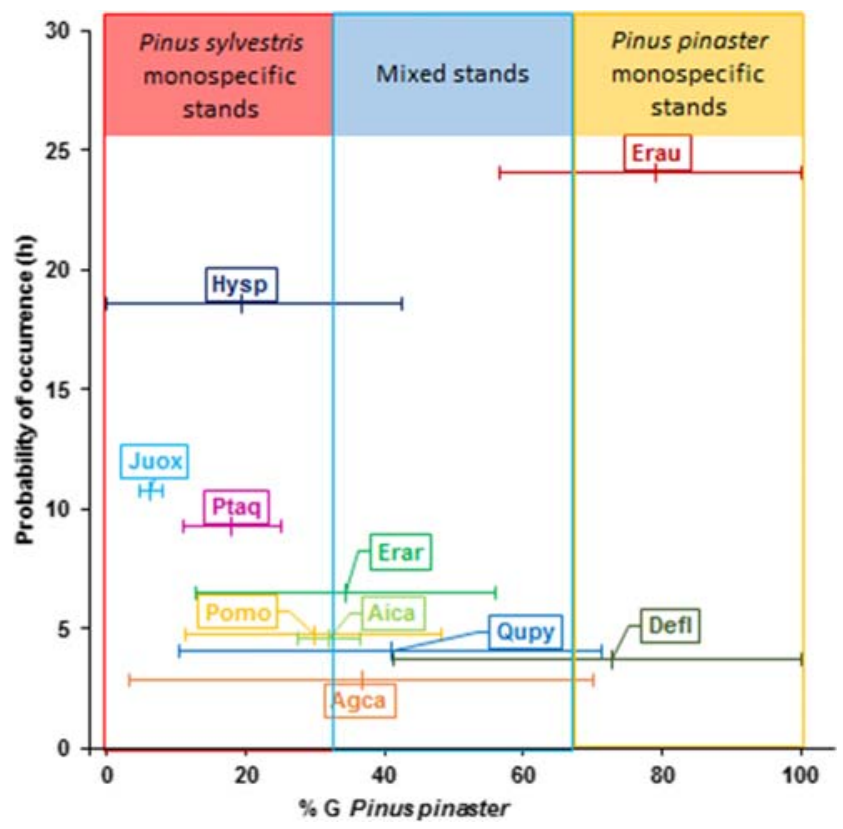

Fig. 4 Location of species optima and $2 \mathrm{t}$ (tolerance) intervals relative to the percentage of basal area of Pinus pinaster, according to fitting of HOF models. Species codes as in Fig. 1

Mestre et al. (2017) also reported that the overstory composition greatly influences the understory in southern temperate forests. The question that arises would therefore be how the tree species of the canopy exert their effect on the understory.

According to the mass ratio hypothesis (Ali and Yan 2017; Grime 1998), the dominant overstory species, P. pinaster and $P$. sylvestris, could exert their effect on the properties of the ecosystem, such as biodiversity, and on subordinate species, i.e., species of the understory, through traits of the dominant species, such as leaf nitrogen concentration or microhabitats provided by such traits. Indeed, in the same experimental device, we found a significant positive correlation between the percentage of basal area of $P$. pinaster and the $\mathrm{C} / \mathrm{N}$ ratio of the fresh leaf litter (see López-Marcos et al. 2018). This finding suggests that the $\mathrm{C} / \mathrm{N}$ ratio of the fresh leaf litter of dominant tree species, as a proxy of the leaf litter decomposition rate (Wang et al. 2016), could be one of the drivers of understory composition; the higher the $\mathrm{C} / \mathrm{N}$ ratio is, the more recalcitrant the leaf litter, i.e., in monospecific stands of $P$. pinaster (Herrero et al. 2016), and in turn the lower $\mathrm{C}$ input into the soil as humic substances. Additionally, the tree species of the canopy can exert their effect on the understory by their influence on other soil properties such as water content. In the same experimental device, the overstory composition was related to soil water content (López-Marcos et al. 2019), indicating that $P$. pinaster tolerated lower soil water content than P. sylvestris, whereas mixed stands occupied areas with intermediate soil moisture. On the other hand, light availability, described as a control agent on forest regeneration (Rodríguez et al. 2007; Ruano et al. 2015) and indirectly measured by the total basal area, seemed to have no effect on the understory species composition and tree regeneration in the studied experimental device (see Fig. 1 and Table 1). In fact, the mixed stands, with higher total basal area than monospecific stands of P. sylvestris (see Table 3 in Annex), maintain a similar understory richness and greater oak regeneration. Nor did leaf litter accumulation seem to have an effect on the understory composition and tree regeneration in our study (see López-Marcos et al. 2019) but leaf litter composition, as mentioned before.

\subsection{Tree regeneration and overstory composition}

According to the recruitment network approach described by Alcántara et al. (2019), a positive relationship is expected between the abundance (basal area) of canopy species and the frequency of recruit saplings, bearing in mind that the light availability (indirectly measured by the total basal area) does not seem to differ significantly between stand types in our experimental device so as to limit this assertion. Thus, higher $P$. sylvestris regeneration occurs in $P$. sylvestris monospecific stands, and higher $P$. pinaster regeneration occurs in $P$. pinaster monospecific stands, although both Pinus species also regenerated in mixed stands. Nevertheless, the highest Q. pyrenaica regeneration is found in mixed stands despite the distance to the acorn source is the same in the three stand types (Fig. 5 in Annex). Taking into account that the distance to the seed source is one of the most important processes limiting the recruitment of tree species (Caughlin et al. 2014), the larger distance from the tree source could explain the scarce and irregular regeneration of $Q$. faginea and Juniperus spp. in the study area (Fig. 5 in Annex).

The next question could be why the regeneration of Q. pyrenaica is greater in mixed stands than in the pure stands, in agreement with Carnevale and Montagnini (2002) who reported that mixed stands facilitate native tree regeneration. In Mediterranean ecosystems, recruitment relies to a greater extent on the capacity of seedlings to endure a combination of multiple stresses and disturbances, such as nutrient or water shortages, wildfires, or herbivore damage (RodríguezCalcerrada et al. 2008). Acorns depend entirely on animals for long-distance dispersion (Yu et al. 2014). Many rodent species, as well as jays, play important roles in the secondary dispersal of oak species via their hoarding behaviors (Gómez 2003; Yu et al. 2014), and it is generally believed that Quercus species can colonize the understory of pine forests via the jayor rodent-mediated dispersion of acorns (Gómez 2003; Yu et al. 2014). Moreover, long-distance dispersal events can determine the spatial pattern of seed distribution at the landscape scale (Gómez 2003). Therefore, one of the issues that deserves more study is why dispersing animals seem to prefer mixed stands instead of pure stands to hoar acorns, if that was the case in the study area. In fact, the greater variability of habitat conditions in mixed stands than in monospecific stands has 
been described as a favorable condition for seed dispersers and germination and growth of native tree species (Carnevale and Montagnini 2002). It could also be that predation in monospecific stands is higher or emergence lower (Carnevale and Montagnini 2002), or simply that the higher soil fertility in mixed stands than in monospecific stands (López-Marcos et al. 2019) favors oak regeneration.

\subsection{Tree regeneration and understory composition}

The importance of the understory vegetation on tree regeneration has already been described, since the understory directly influences soil properties such as temperature and moisture (Rodríguez et al. 2007). Our results showed a relationship between tree regeneration and understory species composition (Fig. 2a). In particular, the regeneration cover of $P$. sylvestris was positively correlated with the cover of some ruderal species, mainly hemicryptophytes (Hypochaeris radicata, Sanguisorba minor) and therophytes (Geranium robertianum, Melampyrum pratense), and negatively linked to the cover of the chamaephyte Erica australis, typical of poor soils (GilLópez et al. 2017) where $P$. sylvestris regenerates worst.

The regeneration cover of $P$. pinaster was positively correlated with the cover of the chamaephyte, Calluna vulgaris, which has been described as an accompanying species in Maritime pine forests (Herranz-Sanz et al. 2008), but was negatively linked to Hypnum spp., mosses with higher moisture requirements than vascular plant species present in $P$. pinaster stands.

The $Q$. pyrenaica regeneration cover was positively correlated with the cover of Erica arborea, Viola montcaunica, Polygala vulgaris, Agrostis castellana, and Ilex aquifolium. All these species have already been described as typical of the Pyrenean oak native forests of the Iberian Peninsula (Velasco-Aguirre 2014); thus, they share with $Q$. pyrenaica the same regeneration niche (see Fig. 4). Mixed stands may favor the presence of this group of species by providing greater soil fertility for intermediate water-stress conditions. This group of accompanying species for native oak could be responsible for the maintenance of the understory richness in mixed stands at the same level as in P. sylvestris monospecific stands, but under higher water-stress conditions (see LópezMarcos et al. 2019).

\subsection{Understory composition change with respect to the overstory composition}

Our results showed a change in the composition of the understory in relation to the overstory composition. The absence of exclusive species in mixed stands could mean that they represent the transition area where $P$. sylvestris and $P$. pinaster coexist (meet and integrate), as previously mentioned for mixed forest of evergreen and deciduous species (Mestre et al. 2017).
As commented above, the overstory composition in the study area was related to soil water content (López-Marcos et al. 2019) and the $\mathrm{C} / \mathrm{N}$ ratio of the leaf litter (López-Marcos et al. 2018). Consequently, species such as Pteridium aquilinum, Pinus sylvestris, or Juniperus spp., characteristic of humid and temperate zones (Rivas-Martínez et al. 2002), showed most of their niche amplitude in P. sylvestris monospecific stands, where soil water retention capacity is higher and the $\mathrm{C} / \mathrm{N}$ ratio of the leaf litter is lower (López-Marcos et al. 2018, 2019). On the opposite end of the gradient, species such as Erica australis, Arctostaphylos uva-ursi, Pinus pinaster, Calluna vulgaris, and Cistus laurifolius, characteristic of sandy well-drained Mediterranean areas (Herranz-Sanz et al. 2008), reached their maximum cover in P. pinaster monospecific stands, where soil water retention capacity is lower and the $\mathrm{C} / \mathrm{N}$ ratio of the leaf litter is higher (LópezMarcos et al. 2018, 2019). In the middle part of this gradient, that is in the mixed stands, where the tree regeneration cover of native species such as $Q$. pyrenaica achieved their maximum values, the optima of other species such as Erica arborea, Aira caryophyllea, Potentilla montana, or Agrostis castellana were found for intermediate values of soil water retention capacity and leaf litter $\mathrm{C} / \mathrm{N}$ ratio (López-Marcos et al. 2018, 2019). The niche amplitude of these species matches the niche amplitude of the Quercus pyrenaica regeneration, encouraging the idea that mixed pine stands allow the presence of a group of species typical of Pyrenean oak native forests in the Iberian Peninsula (Velasco-Aguirre 2014), which are responsible for maintaining understory richness in mixed stands at the same level as in P. sylvestris monospecific stands but under higher water-stress conditions (López-Marcos et al. 2019).

\subsection{Implications for forest management}

It is worth noting here that our results have important implications for forest management in the context of the supply of multiple ecosystem services (Gamfeldt et al. 2013), like biodiversity conservation. Firstly, the mixture of Scots pine and Maritime pine, widely distributed in Spain (Serrada et al. 2008), should continue to be favored over pure stands in the study area because it favors the regeneration of a larger variety of tree species, including the endemic of western Europe Q. pyrenaica (Velasco-Aguirre 2014). This could, therefore, be regarded as an adaptive management strategy for climate change (Temperli et al. 2012) and to promote forest conservation. In fact, Pinus species are suggested as being pioneer species during succession that are usually replaced by latesuccessional Quercus species (Yu et al. 2014). Nevertheless, the maintenance of monospecific pine stands at the landscape scale should also be recommended since species such as Juniperus oxycedrus and Pteridium aquilinum (restricted to Scots pine monospecific stands) or Calluna vulgaris and 
Arctostaphylos uva-ursi (far more abundant in Maritime pine monospecific stands) deserve to be preserved (see species protection status in López-Marcos et al. 2019). Secondly, the maintenance of high understory richness in mixed stands under higher water-stress conditions could be possible by means of the regeneration of $Q$. pyrenaica. A greater variety of understory species associated with the Quercus pyrenaica regeneration and sharing niche amplitude was found. This could be considered as a biodiversity conservation strategy in the current climate change scenario (Felton et al. 2010). Finally, since productivity is often higher in mixtures than in monocultures and can increase by increasing tree species richness (Brockerhoff et al. 2017), the encouraging of native tree regeneration in forest management plans is needed, not only in forest management plans whose objective is to include forest is the main objective. Understanding the ecology of the understory vegetation has important implications for both biodiversity conservation and production-oriented forest management (Nilsson and Wardle 2005). biodiversity as an ecosystem service but also when production

assistance in the characterization and location of plots in the field, the Regional Forest Service of Castilla and León for facilitating the triplet installation and monitoring, and Juan Manuel Díez Clivillé for language improvement. We also thank Erwin Dreyer (Editor-in-Chief), Laurent Begès (Handling Editor), and two anonymous reviewers for their valuable comments to improve the manuscript.

Funding information This research was funded by a predoctoral grant to DLM (BES-2015-072852) and the Project FORMIXING (AGL201451964-C2-1-R) from the Ministry of Economy and Competitiveness of the Spanish Government.

Data availability The data that support the findings of this study are available from Daphne López-Marcos but restrictions apply to the availability of these data, which were used under license for the current study, and so are not publicly available. Data are however available from the authors upon reasonable request and with permission of Felipe Bravo.

\section{Compliance with ethical standards}

Conflict of interest The authors declare that they have no conflict of interest.

\section{Annex}

\section{Conclusion}

The composition of the understory and tree regeneration are influenced by the overstory composition but, according to previous studies, also by the soil conditions (soil water and fertility) that vary with the overstory composition. Species characteristic of humid and temperate zones, including $P$. sylvestris regeneration, dominates in $P$. sylvestris monospecific stands, and typical species of well-drained Mediterranean areas, including $P$. pinaster regeneration, dominate in $P$. pinaster monospecific stands. In mixed stands, where fertility is higher, the regeneration of the western European endemic species, $Q$. pyrenaica, is added to the regeneration of Pinus species. Also, a positive effect of the studied mixture is observed on understory richness, similar to that of P. sylvestris monospecific stands but under lower soil water content. Understory species typical of the native Pyrenean oak forests in the Iberian Peninsula, which share with $Q$. pyrenaica the same regeneration niche, contribute to maintain high understory richness in such mixed pine forests. These results should make us reflect on the use of mixed stands (even when tree species are of the same genus) as a strategy for biodiversity conservation, through native tree regeneration and their accompanying understory species conservation.

Acknowledgments We would like to thank Luis Alfonso Ramos Calvo for his invaluable help with soil sampling, Carmen Blanco and Juan Carlos Arranz from the University of Valladolid (UVa) for their advice in the laboratory analyses, José Riofrío and Cristóbal Ordoñez for their

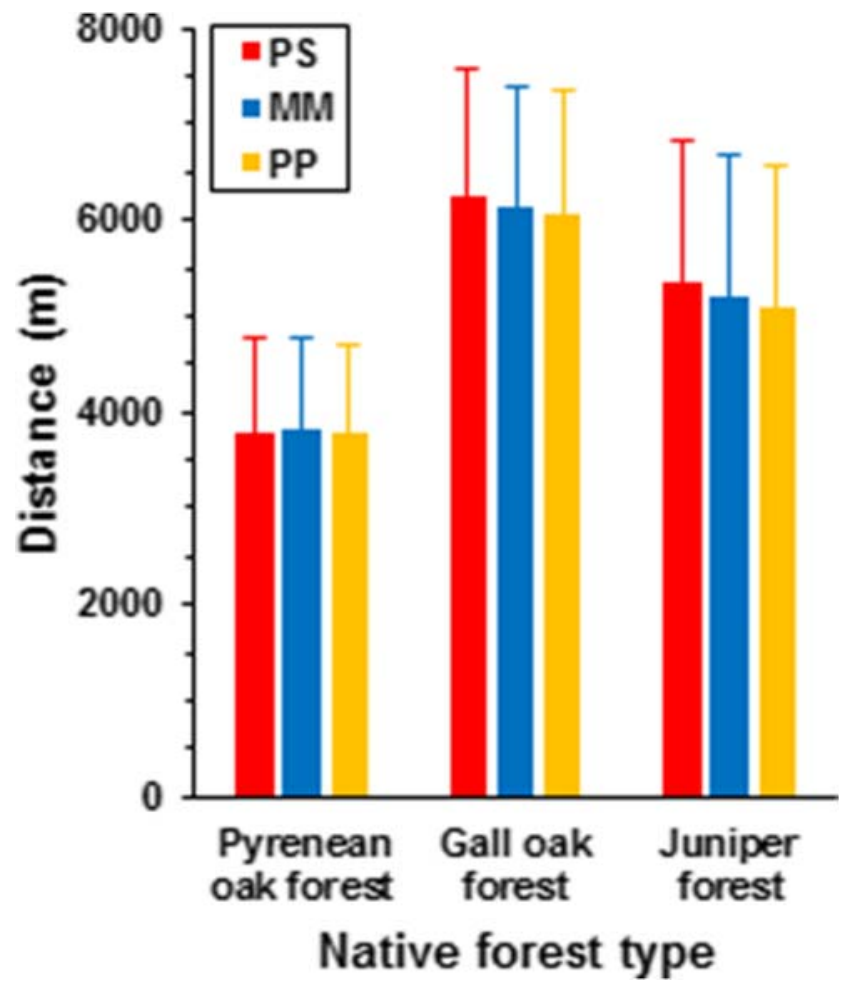

Fig. 5 Distance from the center of the plots of different overstory composition (PS, MM, PP) to the nearest native forest of Pyrenean oak (Quercus pyrenaica Will.), Gall oak (Quercus faginea Lam.), or Juniper (Juniperus spp.), according to the cartographic server (WMS) of the Ministry for the Ecological Transition of the Government of Spain (http://wms.mapama.es/sig/Biodiversidad/) 
Table 3 Descriptive statistics (minimum (min), maximum (max), and mean \pm standard error (mean $\pm \mathrm{SE}$ )) of stand characteristics $(N$ : density (trees $\left.\mathrm{ha}^{-1}\right), G$ : basal area $\left(\mathrm{m}^{2} \mathrm{ha}^{-1}\right)$, Ho: dominant height $(\mathrm{m})$, dq: quadratic mean diameter $(\mathrm{cm})$, and age: normal age (years)) of three types of stands

\begin{tabular}{|c|c|c|c|c|c|c|c|c|c|c|}
\hline & & \multicolumn{3}{|c|}{ Scots pine monospecific stands } & \multicolumn{3}{|c|}{ Mixed stands } & \multicolumn{3}{|c|}{ Maritime pine monospecific stands } \\
\hline & & Min & Max & Mean \pm SE & Min & Max & Mean $\pm \mathrm{SE}$ & Min & Max & Mean $\pm \mathrm{SE}$ \\
\hline \multirow[t]{3}{*}{$N\left(\right.$ trees $\left.\mathrm{ha}^{-1}\right)$} & Total & 509.3 & 821.0 & $684.0 \pm 48.9$ & 523.0 & 1330.0 & $745.0 \pm 120.9$ & 538.0 & 1429.0 & $775.9 \pm 137.1$ \\
\hline & Scots & 495.1 & 806.0 & $660.2 \pm 48.0$ & 241.0 & 764.0 & $429.2 \pm 75.1$ & 0.0 & 283.0 & $59.0 \pm$ \\
\hline & Maritime & 0.0 & 56.6 & $23.5 \pm 8.7$ & 198.0 & 566.0 & $316.0 \pm 56.3$ & 509.0 & 1146.0 & $716.9 \pm 96.6$ \\
\hline \multirow[t]{3}{*}{$G\left(\mathrm{~m}^{2} \mathrm{ha}^{-1}\right)$} & Total & 33.3 & 54.9 & $48.1 \pm 3.2$ & 33.3 & 68.2 & $55.3 \pm 4.9$ & 37.5 & 70.3 & $62.2 \pm 5.2$ \\
\hline & Scots & 30.8 & 54.9 & $44.9 \pm 3.4$ & 13.0 & 45.9 & $25.7 \pm 4.8$ & 0.0 & 3.3 & $0.8 \pm 0.5$ \\
\hline & Maritime & 0.0 & 8.2 & $3.2 \pm 1.1$ & 20.2 & 38.9 & $29.5 \pm 2.9$ & 37.5 & 70.3 & $61.4 \pm 5.1$ \\
\hline \multirow[t]{3}{*}{$\mathrm{dq}(\mathrm{cm})$} & Total & 22.5 & 34.4 & $29.2 \pm 1.7$ & 20.2 & 39.4 & $30.0 \pm 2.8$ & 22.6 & 39.6 & $32.3 \pm 2.5$ \\
\hline & Scots & 22.2 & 32.4 & $28.5 \pm 1.6$ & 16.6 & 40.3 & $27.2 \pm 3.5$ & 0.0 & 15.8 & $5.8 \pm 2.8$ \\
\hline & Maritime & 0.0 & 56.7 & $36.6 \pm 8.2$ & 25.0 & 43.5 & $35.4 \pm 2.8$ & 26.0 & 39.6 & $33.3 \pm 2.2$ \\
\hline \multirow[t]{3}{*}{ Ho (m) } & Total & 16.8 & 22.1 & $19.3 \pm 0.9$ & 13.1 & 24.6 & $18.0 \pm 1.7$ & 12.4 & 20.5 & $16.9 \pm 1.2$ \\
\hline & Scots & 16.6 & 22.1 & $19.2 \pm 0.9$ & 12.3 & 24.3 & $17.1 \pm 1.8$ & 0.0 & 10.8 & $4.2 \pm 1.9$ \\
\hline & Maritime & 0.0 & 24.5 & $17.1 \pm 3.6$ & 14.2 & 25.0 & $19.2 \pm 1.7$ & 13.6 & 20.5 & $17.3 \pm 1.0$ \\
\hline \multirow[t]{2}{*}{ Age (years) } & Scots & 44 & 151 & $99.8 \pm 14.9$ & 44 & 118 & $94.3 \pm 11.7$ & 0 & 0 & $0 \pm 0$ \\
\hline & Maritime & 0 & 0 & $0 \pm 0$ & 49 & 118 & $91.2 \pm 10.2$ & 49 & 118 & $90.8 \pm 10.9$ \\
\hline
\end{tabular}

Table 4 Location of optimum $(\mu)$, predicted maximum probability of occurrence $(h)$ and niche amplitude based on $2 \mathrm{t}$ tolerances, for species with unimodal response with respect to $\% \mathrm{G}$ of Pinus pinaster, as well as the frequency of species appearance in the plots $(\%)$

\begin{tabular}{llllll}
\hline Specie & Model & $h$ & $\mu$ & $2 \mathrm{t}$ & $\%$ \\
\hline Agrostis castellana Boiss. and Reut & IV & 2.83 & 36.68 & 66.94 & 70.59 \\
Aira caryophyllea L. & IV & 4.61 & 31.97 & 9.03 & 41.18 \\
Deschampsia flexuosa (L.) Trin. & V & 3.76 & 72.89 & 58.75 & 41.18 \\
Erica arborea L. & IV & 6.48 & 34.46 & 43.25 & 23.53 \\
Erica australis L. & V & 24.10 & 78.97 & 43.50 & 82.35 \\
Hypnum spp. & V & 18.58 & 19.47 & 42.55 & 94.12 \\
Juniperus oxycedrus L. & IV & 10.74 & 6.37 & 3.21 & 11.76 \\
Potentilla montana Brot. & IV & 4.79 & 29.86 & 36.93 & 52.94 \\
Pteridium aquilinum (L.) Kuhn & IV & 9.28 & 18.02 & 13.95 & 29.41 \\
Quercus pyrenaica Willd. & IV & 4.08 & 40.93 & 60.88 & 29.41 \\
\hline
\end{tabular}

\section{References}

Aguirre N, Günter S, Weber M, Stimm B (2006) Enrichment of Pinus patula plantations with native species in southern Ecuador. Lyonia 10:17-29

Akaike H (1973) Information theory as an extension of the maximum likelihood principle. In: Brillinger D, Gani J, Hartigan J (eds) Second international symposium on information theory. Akademiai Kiado, Budapest, pp 267-281

Alcántara JM, Garrido JL, Rey PJ (2019) Plant species abundance and phylogeny explain the structure of recruitment networks. New Phytol 223:366-376. https://doi.org/10.1111/nph.15774

Alday G, Martínez-Ruiz C, Marrs RH, Bravo F (2010) Influence of harvesting intensity on the floristic composition of natural Mediterranean maritime pine forest. Acta Oecol 36:349-356. https://doi.org/10.1016/j.actao.2010.03.001

Ali A, Yan ER (2017) Functional identity of overstory tree height and understory conservative traits drive aboveground biomass in a subtropical forest. Ecol Indic 83:158-168. https://doi.org/10.1016/ j.ecolind.2017.07.054

Arrieta S, Suárez F (2006) Scots pine (Pinus sylvestris L.) plantations contribute to the regeneration of holly (Ilex aquifolium L.) in mediterranean central Spain. Eur J For Res 125:271-279. https://doi.org/ 10.1007/s10342-006-0121-y

Avendaño-Yáñez ML, Sánchez-Velásquez LR, Meave JA, Pineda-López MR (2016) Can Pinus plantations facilitate reintroduction of endangered cloud forest species? Landsc Ecol Eng 12:99-104. https://doi. org/10.1007/s11355-015-0277-z

Barbier S, Gosselin F, Balandier P (2008) Influence of tree species on understory vegetation diversity and mechanisms involved-a critical review for temperate and boreal forests. For Ecol Manag 254:1-15. https://doi.org/10.1016/j.foreco.2007.09.038

Barkman JJ (1992) Canopies and microclimate of tree species mixtures. In: Cannell MGR, Malcolm DC, Robertson PA (eds) The ecology of mixed-species stands of trees. Blackwell, British Ecological Society, pp 181-187 
Brandtberg PO, Lundkvist H, Bengtsson J (2000) Changes in forest-floor chemistry caused by a birch admixture in Norway spruce stands. For Ecol Manag 130:253-264. https://doi.org/10.1016/S0378-1127(99) 00183-8

Bravo-Oviedo A, Pretzsch H, Ammer C et al (2014) European mixed forests: definition and research perspectives. For Syst 23:518-533. https://doi.org/10.5424/fs/2014233-06256

Brockerhoff EG, Barbaro L, Castagneyrol B, Forrester DI, Gardiner B, González-Olabarria JR, Lyver PO'B, Meurisse N, Oxbrough A, Taki H, Thompson ID, van der Plas F, Jactel H (2017) Forest biodiversity, ecosystem functioning and the provision of ecosystem services. Biodivers Conserv 26:3005-3035. https://doi.org/10.1007/ s10531-017-1453-2

Brooker RW, Maestre FT, Callaway RM et al (2008) Facilitation in plant communities: the past, the present, and the future. J Ecol 96:18-34. https://doi.org/10.1111/j.1365-2745.2007.01295.x

Bruno JF, Stachowicz JJ, Bertness MD (2003) Inclusion of facilitation into ecological theory. Trends Ecol Evol 18:119-125. https://doi. org/10.1016/S0169-5347(02)00045-9

Callaway RM (2007) Positive interactions and interdependence in plant communities. Springer, New York

Carnevale NJ, Montagnini F (2002) Facilitating regeneration of secondary forests with the use of mixed and pure plantations of indigenous tree species. For Ecol Manag 163:217-227

Cattaneo N (2018) Competencia, productividad y cambios a nivel de copa en bosque mixtos de pinos mediterráneos. Señales a nivel de árbol individual. PhD Dissertation, University of Valladolid (Spain)

Caughlin TT, Ferguson JM, Lichstein JW, Bunyavejchewin S, Levey DJ (2014) The importance of long-distance seed dispersal for the demography and distribution of a canopy tree species. Ecology 95: 952-962. https://doi.org/10.1890/13-0580.1

Cavard X, Bergeron Y, Chen HYH, Paré D (2011) Effect of forest canopy composition on soil nutrients and dynamics of the understorey: mixed canopies serve neither vascular nor bryophyte strata. J Veg Sci 22:1105-1119. https://doi.org/10.1111/j.1654-1103.2011.01311. $\mathrm{X}$

Colwell RK (2009) Biodiversity: concepts, patterns and measurement. In: Simon AL (ed) The Princeton guide to ecology. Princeton University Press, Princeton, pp 257-263

Crosby MR, Magill RE, Bauer CR (1992) Index of mosses, 1963-1989. Monographs in systematic botany from the Missouri Botanical Garden 42:1-646 (see pages 1-11)

Felton A, Lindbladh M, Brunet J, Fritz Ö (2010) Replacing coniferous monocultures with mixed-species production stands: an assessment of the potential benefits for forest biodiversity in northern Europe. For Ecol Manag 260:939-947. https://doi.org/10.1016/j.foreco. 2010.06 .011

Gamfeldt L, Snäll T, Bagchi R, Jonsson M, Gustafsson L, Kjellander P, Ruiz-Jaen MC, Fröberg M, Stendahl J, Philipson CD, Mikusiński G, Andersson E, Westerlund B, Andrén H, Moberg F, Moen J, Bengtsson J (2013) Higher levels of multiple ecosystem services are found in forests with more tree species. Nat Commun 4:1340. https://doi.org/10.1038/ncomms2328

Gil-López J, Segarra-Moragues JG, Désamoré A et al (2017) Different historical backgrounds determine contrasting phylogeographical patterns in two co-distributed Erica species (Ericaceae) across the Strait of Gibraltar. Bot J Linn Soc 185:359-375. https://doi.org/10. 1093/botlinnean/box066

Gómez JM (2003) Spatial patterns in long-distance dispersal of Quercus ilex acorns by jays in a heterogeneous landscape. Ecography 26: 573-584

Gómez-Aparicio L, Zavala MA, Bonet FJ, Zamora R (2009) Are pine plantations valid tools for restoring Mediterranean forests ? An assessment along abiotic and biotic gradients. Ecol Appl 19:2124 2141
Grace JB, Tilman D (2003) Perspectives in plant competition. The Blackburn Press, Caldwell

Grime JP (1998) Benefits of plant diversity to ecosystems: immediate, filter and founder effects. J Ecol 86:902-910. https://doi.org/10. 1046/j.1365-2745.1998.00306.x

Herranz-Sanz JM, Martín-Herrero J, Copete-Carreño MA (2008) Caracterización florística de los pinares naturales de Pinus pinaster Aiton en Castilla-La Mancha. INIA-Ministerio de Ecudación y Ciencia, Madrid

Herrero C, Turrión MB, Pando V, Bravo F (2016) Carbon content of forest floor and mineral soil in Mediterranean Pinus spp. and oak stands in acid soils in Northern Spain. For Syst. https://doi.org/10. 5424/fs/2016252-09149

Hill MO (1992) Mixtures as habitats for plants (discussion). In: Cannell MGR, Malcolm DC, Robertson PA (eds)The ecology of mixed-species stands of trees. British Ecological Society, Blackwell (UK), pp 301-302

Huisman J, Olff H, Fresco LFM (1993) A hierarchical set of models for species response analysis. J Veg Sci 4:37-46. https://doi.org/10. $2307 / 3235732$

Inoue T, Fukuzawa K, Watanabe T, Yoshida T, Shibata H (2017) Spatial pattern of soil nitrogen availability and its relationship to stand structure in a coniferous-broadleaved mixed forest with a dense dwarf bamboo understory in northern Japan. Ecol Res 32:227-241. https:// doi.org/10.1007/s11284-017-1434-7

Jactel H, Gritti ES, Drössler L et al (2018) Positive biodiversityproductivity relationships in forests: climate matters. Biol Lett 14: 12-15. https://doi.org/10.1098/rsbl.2017.0747

Jansen F, Oksanen J (2013) How to model species responses along ecological gradients - Huisman-Olff-Fresco models revisited. J Veg Sci 24:1108-1117. https://doi.org/10.1111/jvs. 12050

Johnson JB, Omland KS (2004) Model selection in ecology and evolution. Trends Ecol Evol 19:101-108. https://doi.org/10.1016/j.tree. 2003.10.013

Köppen W (1936) Das geographische system der klimate. In: Handbuch der Klimatologie. Velag von Gebruder Borntraeger. Berlin. pp 7-30

Korboulewsky N, Perez G, Chauvat M (2016) How tree diversity affects soil fauna diversity: a review. Soil Biol Biochem 94:94-106. https:// doi.org/10.1016/j.soilbio.2015.11.024

Lawesson JE, Oksanen J (2002) Niche characteristics of Danish woody species as derived from coenoclines. J Veg Sci 13:279-290

Löf M, Ammer C, Coll L, Drössler L, Huth F, Madsen P, Wagner S (2018) Regeneration patterns in mixed-species stands. In: Bravo-Oviedo A, Pretzsch H, del Río M (eds) Dynamics, silviculture and management of mixed forests. Springer, Cham, pp 103-130

López-Marcos D, Martínez-Ruiz C, Turrión MB, Jonard M, Titeux H, Ponette Q, Bravo F (2018) Soil carbon stocks and exchangeable cations in monospecific and mixed pine forests. Eur J For Res 137:831-847. https://doi.org/10.1007/s10342-018-1143-y

López-Marcos D, Turrión MB, Bravo F, Martínez-Ruiz C (2019) Understory response to overstory and soil gradients in mixed vs monospecific Mediterranean pine forests. Eur J For Res 138(6): 939-955. https://doi.org/10.1007/s10342-019-01215-0

Mestre L, Toro-Manríquez M, Soler R, Huertas-Herrera A, MartínezPastur G, Lencinas MV (2017) The influence of canopy-layer composition on understory plant diversity in southern temperate forests. For Ecosyst 4:6-13. https://doi.org/10.1186/s40663-017-0093-z

Nilsson MC, Wardle DA (2005) Understory vegetation as a forest ecosystem driver: evidence from the northern Swedish boreal forest. Front Ecol Environ 3:421-428. https://doi.org/10.1890/15409295(2005)003[0421:UVAAFE]2.0.CO;2

Oksanen J (2016) Vegan: an introduction to ordination. https://cran.rprojetct.org/web/packages/vegan/vignettes/introvegan.pdf

Olthoff A, Martínez-Ruiz C, Alday JG (2016) Distribution patterns of forest species along an Atlantic-Mediterranean environmental 
gradient: an approach from forest inventory data. Forestry 89:46-54. https://doi.org/10.1093/forestry/cpv031

Pigott CD (1990) The influence of evergreen coniferous nurse-crops on the field layer in two woodland communities. J Appl Ecol 27:448459. https://doi.org/10.2307/2404293

Pretzsch H, Block J, Dieler J et al (2010) Comparison between the productivity of pure and mixed stands of Norway spruce and European beech along an ecological gradient. Ann For Sci 67:712-712. https://doi.org/10.1051/forest/2010037

R Development Core Team (2016) R: a language and environment for statistical computing. https ://www.r-proje ct.org/

Riofrío J, Del Río M, Bravo F (2017a) Mixing effects on growth efficiency in mixed pine forests. Forestry 90:381-392. https://doi.org/10. 1093/forestry/cpw056

Riofrío J, del Río M, Pretzsch H, Bravo F (2017b) Changes in structural heterogeneity and stand productivity by mixing Scots pine and maritime pine. For Ecol Manag 405:219-228. https://doi.org/10.1016/j. foreco.2017.09.036

Riofrío J, del Río M, Maguire DA, Bravo F (2019) Species mixing effects on height-diameter and basal area increment models for Scots pine and maritime pine. Forests 10:249. https://doi.org/10.3390/ f10030249

Rivas-Martínez S (1987) Memoria del mapa de series de vegetación de España. Serie Técnica, Madrid

Rivas-Martínez S, Díaz TE, Fernández-González F et al (2002) Vascular plant communities of Spain and Portugal. Addenda to the syntaxonomical checklist of 2001. Itinera Geobot 15:5-922

Rodríguez E, Juez L, Guerra B, Bravo F (2007) Análisis de la regeneración natural de Pinus pinaster Ait. en los arenales de Almazán-Bayubas (Soria, España). For Syst 16:25-38

Rodríguez-Calcerrada J, Pardos JA, Gil L et al (2008) Light response in seedlings of a temperate (Quercus petraea) and a sub-Mediterranean species (Quercus pyrenaica): contrasting ecological strategies as potential keys to regeneration performance in mixed marginal populations. Plant Ecol 195:273-285. https://doi.org/10.1007/s11258007-9329-2

Rodríguez-Calcerrada J, Nanos N, del Rey MC, de Heredia UL, Escribano R, Gil L (2011) Small-scale variation of vegetation in a mixed forest understory is partly controlled by the effect of overstory composition on litter accumulation. J For Res 16:473-483. https:// doi.org/10.1007/s10310-010-0237-2
Ruano I, Manso R, Fortin M, Bravo F (2015) Extreme climate conditions limit seed availability to successfully attain natural regeneration of Pinus pinaster in sandy areas of central Spain. Can J For Res 1802: 1795-1802. https://doi.org/10.1139/cjfr-2015-0257

Saetre P, Saetre LS, Brandtberg P-O et al (1997) Ground vegetation composition and heterogeneity in pure Norway spruce and mixed Norway spruce-birch stands. Can J For Res 27:2034-2042. https://doi.org/10.1139/x97-177

Saetre P, Brandtberg PO, Lundkvist H, Bengtsson J (1999) Soil organisms and carbon, nitrogen and phosphorus mineralisation in Norway spruce and mixed Norway spruce - birch stands. Biol Fertil Soils 28: 382-388. https://doi.org/10.1007/s003740050508

Serrada R, Montero G, Reque JA (2008) Compendio de selvicultura aplicada en España. Instituto Nacional de Investigación y Tecnología Agraria y Alimentaria-INIA, Madrid

Soil-Survey-Staff (2014) Keys to soil taxonomy, 12th edn. USDANatural Resources Conservation Service, Washington

Temperli C, Bugmann H, Elkin C (2012) Adaptive management for competing forest. Ecol Appl 22:2065-2077. https://doi.org/10.1890/120210.1

Toïgo M, Vallet P, Perot $\mathrm{T}$ et al (2015) Overyielding in mixed forests decreases with site productivity. J Ecol 103:502-512. https://doi. org/10.1111/1365-2745.12353

Tutin TG, Heywood VH, Burges NA, et al (1964-1980) Flora Europaea. Cambridge University Press, Cambridge (UK)

Velasco-Aguirre P (2014) Comprehensive study of Quercus pyrenaica Willd. forests at Iberian Peninsula: indicator species, bioclimatic, and syntaxonomical characteristic. $\mathrm{PhD}$ Dissertation, Universidad Complutense de Madrid (Spain)

Wang J, You Y, Tang Z et al (2016) A comparison of decomposition dynamics among green tree leaves, partially decomposed tree leaf litter and their mixture in a warm temperate forest ecosystem. J For Res 27:1037-1045. https://doi.org/10.1007/s11676-016-0248-8

Yu F, Wang D, Yi X et al (2014) Does animal-mediated seed dispersal facilitate the formation of Pinus armandii-Quercus aliena var. acuteserrata forests? PLoS ONE 9(2):e89886. https://doi.org/10. 1371/journal.pone.0089886

Publisher's note Springer Nature remains neutral with regard to jurisdictional claims in published maps and institutional affiliations. 